\title{
Construction of closed horizontal drainage on irrigated lands and determination of its parameters
}

\author{
Safo Vafoev ${ }^{1 *}$, Nuzamadin Dauletov ${ }^{2}$, Ilkhomjon Turdibekov ${ }^{1}$, Rustam Vafoev ${ }^{1}$, and Ozoda \\ Vafoeva ${ }^{1}$ \\ ${ }^{1}$ Tashkent Institute of Irrigation and Agricultural Mechanization Engineers, Tashkent, Uzbekistan \\ ${ }^{2}$ Ministry of Water Resources of the Republic of Uzbekistan, Tashkent, Uzbekistan
}

\begin{abstract}
The article describes the construction technology of closed horizontal drainage in irrigated areas, presents the results of theoretical studies to determine the depth of drainage, the width of the drainage trench, the diameter of the drainage pipe, the thickness of the filter material, the distance between the drains and the drainage module. According to the results of theoretical studies, the average drainage depth is $1.5 \mathrm{~m}$, the width of the drainage trench is $0.3 \mathrm{~m}$, the diameter of the drainage pipe is $0.1 \mathrm{~m}$, the thickness of the filtration material is $0.1 \mathrm{~m}$. The distance between the drains is $150 \mathrm{~m}$ with the drainage module $0.1 \mathrm{l} / \mathrm{s}$, the distance between drains is $180 \mathrm{~m}$ with a drain module of $0.12 \mathrm{l} / \mathrm{s}$, and the distance between drains is $210 \mathrm{~m}$ with a drain module of $0.14 \mathrm{l} / \mathrm{s}$.
\end{abstract}

\section{Introduction}

Drainage has great importance in improving the condition (amelioration) of lands. Scientists of the former Central Asian Research Institute of Irrigation (at present - the Scientific Research Institute of Irrigation and Water Problems of the Ministry of Water Resources of the Republic of Uzbekistan) V.Dukhovny, Yu.Pulatov, V.Berdyansky, A.Mirsagatov, A.Abrorkhadzhaev, E.Tomin, A.Abirov, and others, who were engaged in land amelioration activities during the 1960-1988 years, made a huge contribution to the construction of open and closed horizontal drainages in Central Asia.

According to the recommendations of the scientists mentioned above, 30 percent of irrigated land should be open, and 70 percent should be installed as closed. However, due to the lack of scientifically-importance technology for the construction of closed horizontal drainage, scientists' recommendations are not being followed. The drains built in 1966 using as the world's first drainage machine designed are still in usage today.

In our country, 39 thousand $\mathrm{km}$ of closed horizontal drainage have been built, of which 70 percent are out of order, and other remaining 30 percent are being operated with very low efficiency. One of the main reasons for this is increasing the groundwater level. During the operation of imported drainage machines, drains are laid to a depth of $3.0 \mathrm{~m}$. At present, the groundwater level has risen to a depth of $1.5 \mathrm{~m}$ from the earth's surface.

* Corresponding author: safo195400@gmail.com 
Therefore, in places, open drainages are built, and due to a decrease in the area for agricultural crops, the land-use coefficient is being decreased. According to preliminary calculations, currently, open drainages occupy an area of 250 thousand hectares. Long-term observations show that drainages fail because the groundwater level is almost equal to the water level in the reservoirs into which they are removed.

\section{Methods}

There are two solutions to this problem:

- the first - choosing other deeper reservoirs, where groundwater can easily flow out, but this solution requires more expenses.

- the second - improving the design of machines for the construction of drainage and build drainage to a depth of $1.5 \mathrm{~m}$.

The research aims to determine the parameters of closed horizontal drainage in irrigated areas (diameter of the drainage pipe, filtration material and its thickness, installation depth, and distance between drains).

The horizontal drainage structure is shown in Figure 1. It consists of a drainage pipe 3 installed at a certain depth, a filtration material 4 wrapped around it, holes 5 for water entering the drainage pipe, inspection wells 2 installed at regular intervals (100 or $400 \mathrm{~m})$, and a cover 1 of the inspection well.
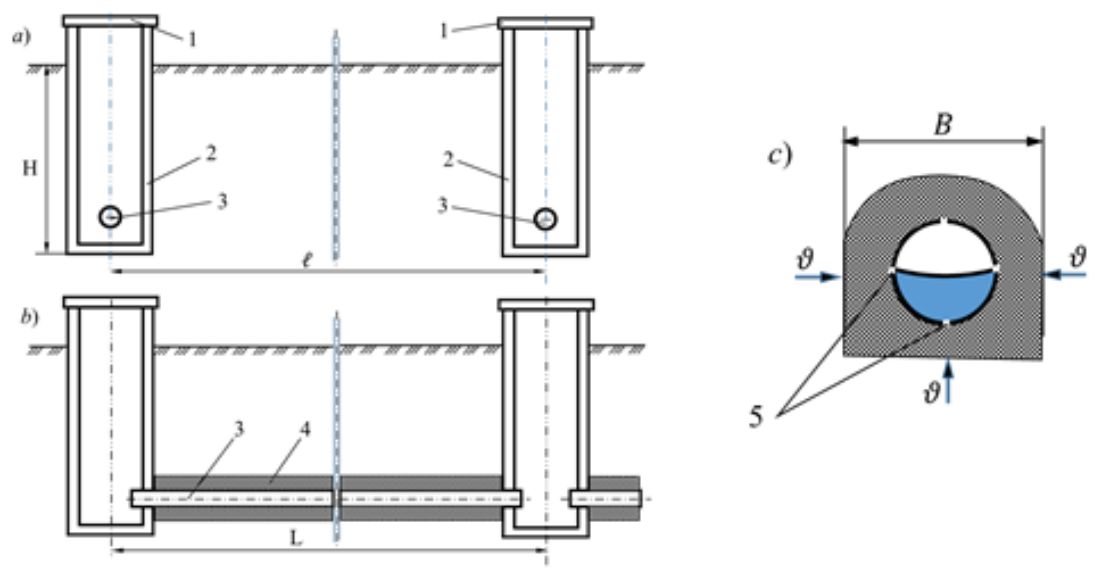

Fig. 1. Closed drainage design: $a$ is cross-section; $b$ is longitudinal section; $c$ is drain pipe and the filter wrapped around it.

Construction technology of horizontal drainage. A drainage trench is dug with an appropriate slope and a drainage pipe and its filtration material installed on it. In this case, the length of the drainage can be $400 \ldots 1200 \mathrm{~m}$. The soil from the drainage trench is filled up and compacted. Inspection wells installed at certain intervals $(100$ or $400 \mathrm{~m})$.

The function of control wells is to monitor the operation of the drain and their exploitation when flushing the drain pipe. In this case, of course, the first inspection well should be installed at the beginning/top of the drain. If the water inside the drain pipe is discharged into an open drain, the asbestos pipe is connected to the end of the closed drain pipe, which is diverted to the open drain at a certain distance [4]. 


\section{Results and Discussion}

Typically, drainage pipes of different diameters are installed over large areas to transfer water from a small-diameter pipe to a large-diameter pipe (for example, from a $100 \mathrm{~mm}$ pipe to a $150 \mathrm{~mm}$ pipe, from a $150 \mathrm{~mm}$ pipe to a $200 \mathrm{~mm}$ pipe, from a $200 \mathrm{~mm}$ pipe to a pipe diameter $250 \mathrm{~mm}$, etc.), and the last pipe collects all the water and discharges it into an open drain $[1,2,6]$.

The volume of water taken from one hectare can be determined using the following formula:

$$
V=10^{4} \cdot h_{o} \cdot\left(W_{c}-W_{o}\right), m^{3}
$$

where $h_{o}$ is a layer of water-saturated soil, $m ; W_{c}$ is moisture content of water-saturated soil $\left(W_{c}=0.28 \ldots 0.30\right) ; W_{o}$ is optimum soil moisture $\left(W_{o}=0.10 \ldots 0.18\right)$.

Using the formula (1), we determine the volume of water $\mathrm{D}\left(\mathrm{m}^{3} / \mathrm{ha}\right)$ entering the drainage system.

For example, the magnitude of the drainage load with single irrigation of a hectare $D=$ $10^{4} \cdot h_{o} \cdot\left(W_{c}-W_{o}\right)=10^{4} \cdot 0.8 \cdot(0.3-0.18)=960 \mathrm{~m}^{3} / \mathrm{ha}$.

The drainage module can be determined by the following formula [5]:

$$
q=\frac{D}{T_{d}}, \frac{m^{3}}{\text { year } \cdot h a}
$$

where $T_{\text {д }}$ is the number of days in a year.

Formula (2) can be written as follows:

$$
q=\frac{D}{T_{d}}=\frac{1000 \cdot D}{365 \cdot 24 \cdot 3600}=\frac{D}{86.4 \cdot 365}=\frac{D}{31536}, \frac{l}{\sec \cdot h a}
$$

Drainage module for heavy sandy soils:

$$
q_{\mathrm{oc}}=\frac{D}{31536}=\frac{3153,6}{31536}=0.10 \mathrm{l} /(\mathrm{sec} \cdot \mathrm{ha})=0.36 \mathrm{~m}^{3} / \text { hour } .
$$

The drainage module can be expressed as follows:

$$
q_{\mathrm{oc}}=\frac{\pi \cdot d_{\mathrm{T}}^{2}}{4} \cdot n \cdot \vartheta_{\mathrm{oc}}
$$

where $d_{\mathrm{T}}$ is the diameter of the holes on the surface of the drainage pipe, $m ; \mathrm{n}$ is the number of holes in one meter of the drainage pipe, $\vartheta_{\text {oc }}$ is the groundwater velocity, $m / h$.

From formula (4), $\quad \vartheta_{\mathrm{oc}}=\frac{4 \cdot q_{\mathrm{oc}}}{\pi \cdot d_{\mathrm{T}}^{2} \cdot n}=\frac{4 \cdot 0.36}{3.14 \cdot\left(4 \cdot 10^{-3}\right)^{2} \cdot 400}=75 \mathrm{~m} / \mathrm{h}=0,02 \mathrm{~m} / \mathrm{s}$.

If there are four holes in each centimeter of the pipe, then the number of holes in a meter of the drainage pipe is $n=4 \cdot 100=400$ pcs.

Consequently, the water velocity in heavy sandy soils is $75 \mathrm{~m} / \mathrm{h}$, and the distance between drain pipes is $\ell=150 \mathrm{~m}$.

The volume of water for each meter of drainage is:

$$
Q_{1 m}=1 \cdot \ell \cdot h_{o} \cdot\left(W_{c}-W_{o}\right)=1 \cdot 150 \cdot 0.8 \cdot(0.30-0.18)=14.4 \mathrm{~m}^{3} / h
$$


If the area of one hectare is 10 thousand $\mathrm{m}^{2}$ and the drainage pipe collects water at a distance of $150 \mathrm{~m}$, then the width $b$ of the area can be determined as follows:

$10000=150 \cdot b$, and therefore $b=66.67 \mathrm{~m}$.

If each meter of the drainage pipe receives $14.4 \mathrm{~m}^{3}$ of water per hour, then the volume of water at a distance of $66.67 \mathrm{~m}$ will be $14.4 \cdot 66.67=960 \mathrm{~m}^{3}$, which is equal to the volume of water flowing out from one hectare.

Drainage module for sandy soils:

$$
\begin{gathered}
q_{\mathrm{c}}=\frac{D}{31536}=\frac{3784,32}{31536}=0,12 \mathrm{l} /(\mathrm{sec} \cdot \mathrm{ha})=0,432 \mathrm{~m}^{3} / \mathrm{h} . \\
\vartheta_{\mathrm{c}}=\frac{4 \cdot q_{\mathrm{c}}}{\pi \cdot d_{\mathrm{T}}^{2} \cdot n}=\frac{4 \cdot 0,432}{3,14 \cdot\left(4 \cdot 10^{-3}\right)^{2} \cdot 400}=90 \mathrm{~m} / \mathrm{h}=0,025 \mathrm{~m} / \mathrm{sec} .
\end{gathered}
$$

Therefore, the distance between the drains is $\ell=180 \mathrm{~m}$.

Drainage module for medium sandy soils

$$
\begin{gathered}
q_{u s}=\frac{D}{31536}=\frac{4415.04}{31536}=0.14 \mathrm{l} /(\mathrm{sec} \cdot \mathrm{ha} a)=0.504 \mathrm{~m}^{3} / \mathrm{h} \\
\vartheta_{u s}=\frac{4 \cdot q_{u s}}{\pi \cdot d_{\mathrm{T}}^{2} \cdot n}=\frac{4 \cdot 0.504}{3.14 \cdot\left(4 \cdot 10^{-3}\right)^{2} \cdot 400}=105 \mathrm{~m} / \mathrm{h}=0.029 \mathrm{~m} / \mathrm{sec}
\end{gathered}
$$

Therefore, the distance between the drains is $\ell=210 \mathrm{~m}$.

The volume of water flowing through the drain pipe can be determined using the following formula:

$$
\begin{aligned}
& Q=\frac{\pi \cdot d^{2}}{4} \cdot \vartheta_{q}= \frac{\pi \cdot d^{2}}{4} \cdot \sqrt{2 \cdot g \cdot h}=\frac{3.14 \cdot 0.1^{2}}{4} \cdot \sqrt{2 \cdot 10 \cdot 0.03}=0.00785 \cdot 0.632=0.006 \frac{\mathrm{m}^{3}}{\mathrm{sec}}= \\
&=22 \mathrm{~m}^{3} / \mathrm{h} .
\end{aligned}
$$

where $d$ is the diameter of the drainage pipe, $m ; \vartheta_{q}$ is water flow rate in the pipe, $m / s ; h$ is lifting height of the drainage pipe, $m$.

If during every hour $22 \mathrm{~m}^{3}$ of water passes through the drainage pipe, then $960 \mathrm{~m}^{3}$ of water from a hectare flows out in 44 hours, that is 1.83 days.

In this case, the depth of the drainage trench for all drainages was taken equal to $\mathrm{H}=1.6$ $m$, and its width was $\mathrm{B}=0.3 \mathrm{~m}$.

Water supplied from the soil's surface for irrigation of crops is absorbed into the soil, flushes out salts from the soil, and the mixture of water and salt enters the drainage pipes. In this case, layers are formed moistened with $h_{\mathrm{H}}$ and saturated with water $h_{o}$ (Fig. 2).

These heights determined experimentally are $h_{n}=0.7 \mathrm{~m}$ and $h_{o}=0.8 \mathrm{~m}$ respectively.

The drainage depth $H$ can be determined as follows [4]:

$$
H=h_{n}+h_{o}+d=0.7+0.8+0.1=1.6 m
$$

It can be seen from the figure that the groundwater boundary has a curved line; it is located low in places that are close to the drainage pipes and high in the middle of the distance between the drainage pipes. 


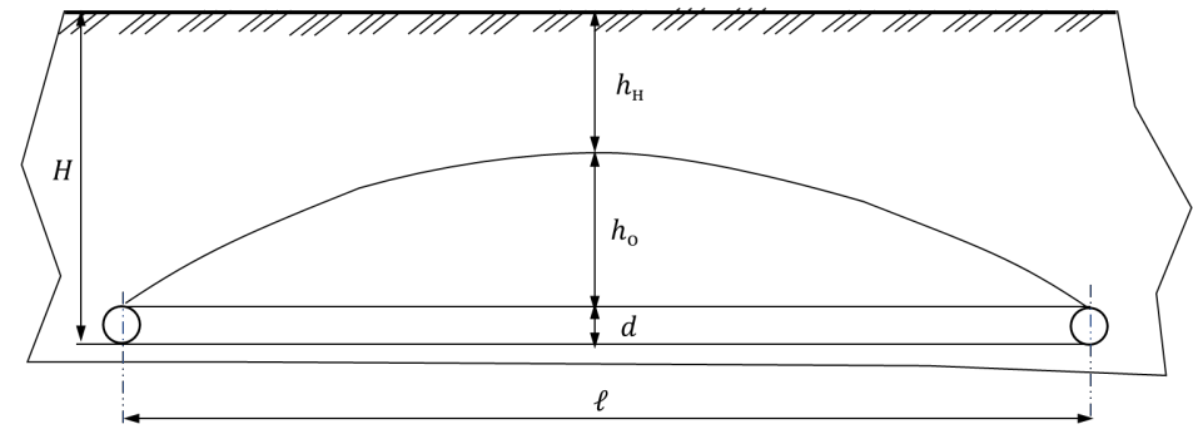

Fig. 2. Curvilinear diagram of the distribution of the wetted and water-saturated layer.

The values of the results obtained from theoretical calculations and experiments are shown in the following table.

Table. Values of the results obtained from theoretical calculations and experiments.

\begin{tabular}{|c|c|c|c|c|c|c|c|}
\hline 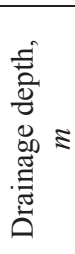 & 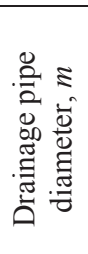 & 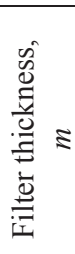 & 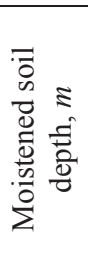 & 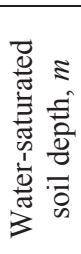 & 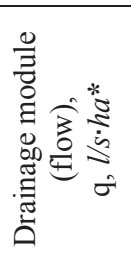 & $\begin{array}{l}\text { Water velocity, } \\
\qquad \begin{array}{l}m / h \\
\vartheta\end{array} \frac{4 \cdot q}{\pi \cdot d_{\mathrm{T}}^{2} \cdot n}\end{array}$ & $\begin{array}{l}\text { Distance } \\
\text { between } \\
\text { drains, } m \\
\ell=2 \cdot \vartheta \cdot t\end{array}$ \\
\hline \multirow{6}{*}{1.6} & \multirow{6}{*}{0.1} & \multirow{6}{*}{0.1} & \multirow{6}{*}{0.7} & \multirow{6}{*}{0.8} & 0.10 & 75 & 150 \\
\hline & & & & & 0.12 & 90 & 180 \\
\hline & & & & & 0.14 & 105 & 210 \\
\hline & & & & & 0.16 & 120 & 240 \\
\hline & & & & & 0.18 & 135 & 270 \\
\hline & & & & & 0.20 & 150 & 300 \\
\hline
\end{tabular}

Drainage modulus values were determined based on the field experience [3].

\section{Conclusions}

According to practical results obtained through experiments and theoretical calculations, the average drainage depth is $1.6 \mathrm{~m}$, the width of the drainage trench is $0.3 \mathrm{~m}$, the diameter of the drainage pipe is $0.1 \mathrm{~m}$, the thickness of the filter material is $0.1 \mathrm{~m}$, the distance between drains is $150 \mathrm{~m}$ at drainage module $0.10 \mathrm{l} / \mathrm{s}$, the distance between drains $180 \mathrm{~m}$ with drainage module $0.12 \mathrm{l} / \mathrm{s}$, the distance between drains $210 \mathrm{~m}$ with drainage module $0.14 \mathrm{l} / \mathrm{s}$, the distance between drains $240 \mathrm{~m}$ with drainage module $0.16 \mathrm{l} / \mathrm{s}$, the distance between drains was $270 \mathrm{~m}$ with a drainage module of $0.18 \mathrm{l} / \mathrm{s}$ and the distance between drains was $300 \mathrm{~m}$ with a drainage module of $0.20 \mathrm{l} / \mathrm{s}$.

\section{References}

1. Vafoev S.T. Scientific bases of construction and reliable operation of the closed horizontal drainage. - Tashkent: "Fan" Publishers. p. 124. (2005).

2. R.Vafoev, S.Vafoev, S.Akhmedov and Sh.Imomov. Method for sealing ground in trench closed drain. IOP Conf. Series: Earth and Environmental Science 614 (2020) 012093 doi:10.1088/1755-1315/614/1/012093.

3. O.Vafoeva. Hydromechanical Method of Soil Compaction. IOP Conf. Series: Materials Science and Engineering 883 (2020) 012061. 
4. Kakharov Z. V., Mexmonov M. Kh. Surface compaction of soils Engineering Solutions e-science journal 1(1), pp. 4-6. (2018).

5. Makhmutov M. M., Sakhapov R. L. On the quality of compaction of soil subgrade Izvestia KGASU 2(32), pp. 289-294. (2012)

6. Mikheev V.V., Saveliev S.V. Modeling the characteristics of deformable soils during compaction with cylindrical working bodies of rollers Vestnik SibADI 4(50), pp. 2936. (2016).

7. Osipov V.I., Karpenko F.S. and Rumyantseva N.A. Active porosity and its effect on the physicomechanical properties of clay soils Journal Geoecology Engineering geology Hydrogeology Geocryology pp.262-269. (2014).

8. Saveliev S.V., Buryi G.G., Poteryaev I.K. and Beloded A.S. The use of an innovative device for monitoring the quality of soil compaction by the road roller construction machine Izvestiya TulGU Technical science 3, pp. 212-217. (2016).

9. Sultanov T.Z., Vafoev S.T. and Vafoeva O.S., Theoretical bases of soil compaction journal irrigation and melioration Tashkent 2(16), pp. 38-41. (2019).

10. Ramazanov A. About depth of draining on salted land journal irrigation and melioration Tashkent 1(11), pp. 5-8. (2018).

11. Akshaya K. S., Ranjan K. M. Effect of compaction energy on engineering properties of fly ash-granite dust stabilized expansive soil International Journal of Engineering and Technology, pp. 71617-71624. (2015).

12. Kokoev M.N., Boriev V.S. The method of compaction of planting grounds, Russian Federation patent 2158802. (2000).

13. Khammadov K., Lukutin I.N., Voitovich I.V., A device for compaction of ground drainage backfill (A.c. 123925). B.I. 23. (1985).

14. Saveliev S.V., Buryi G.G., Poteryaev I.K. and Beloded A.S., The use of an innovative device for monitoring the quality of soil compaction by the road roller construction machine Izvestiya TulGU Technical science 3, 212-217 pages. (2016).

15. Sultanov T. Z., Vafoev S.T. and Vafoeva O.S., Theoretical bases of soil compaction journal irrigation and melioration Tashkent 2(16), pp 38-41. (2019).

16. Akshaya K.S., Ranjan K.M., 2015 Effect of compaction energy on engineering properties of fly ash-granite dust stabilized expansive soil International Journal of Engineering and Technology, 71617-71624 pages.

17. Ramazanov A. Land amelioaration and irrigated agriculture. - Tashkent: "Fan" Publishers, 2020. 192 p.

18. Rakhimbaev. F.M, Khamidov M.Kh. Agricultural melioration. - Tashkent: "Uzbekistan" Publishers. p. 366. (1996).

19. Ramazanov A. About depth of draining on salted land journal irrigation and melioration Tashkent 1(11), pp. 5-8. (2018).

20. Rakhimbaev F.M..Shukurlaev H.I. Drainage amelioration in agriculture. -Tashkent: "Mekhnat" Publishers. p. 204. (1996). 